\title{
IZOBRAŽEVANJE ODRASLIH ZA DUŠEVNO ZDRAVJE
}

\author{
Izobraževanje - preventiven ukrep \\ pri doseganju duševnega zdravja
}

V

prispevku razmišljam o vseživljenjskem permanentnem izobraževanju, o njegovem vplivu na kakovost človekovega življenja, predvsem z vidika duševnega zdravja. Človekovo življenje in razvoj je pomembno oblikovalo prav učenje. Zamisel o permanentnosti učenja, njegova filozofija sega že $\mathrm{v}$ dvajseta leta tega stoletja (B. Jeaxlee in E. Lindeman), bolj uradno in strokovno pa so začeli predstavljati to idejo pred dobrimi tremi desetletji. Uveljavljati jo je začel predvsem Unesco, pomemben mejnik pa je bila Unescova druga konferenca o izobraževanju odraslih v Montrealu leta 1960.

\section{VSEŽIVLJENJSKO IZOBRAŽEVANJE IN KAKOVOST ŽIVLJENJA}

Idejo permanentnega vseživljenjskega izobraževanja zasledimo že v delu Pampedia J. A. Komenskega, ki se je rodil leta 1592. Skoraj 400 let kasneje, to je leta 1970, je prvo temeljito strokovno utemeljitev permanentnega izobraževanja objavil Paul Lengrand v knjigi Uvod v' permanentno izobraževanje (Introduction of Lifelong Education).

Lengrand pojasnjuje, zakaj je potreba po permanentnem izobraževanju čedalje večja. Predstavljivost današnjega sveta je za človeka mogoča samo, če vedno znova sprejema in prepoznava hitro se spreminjajoče podatke o tem svetu. Zaradi naraščanja števila prebivalcev in daljše življenjske dobe se povečujejo tudi zahteve po izobraževanju. $\mathrm{V}$ posameznikovem življenju se razmerje med delovnim in prostim časom podaljšuje $\mathrm{v}$ korist slednjega. V sodobni civilizaciji se vrednote, vzori in odnosi med ljudmi menjajo hitreje kot generacije. Industrijska družba si prizadeva zadovoljiti vse potrebe, hkrati pa kot porabniška družba proizvaja vedno nove potrebe, da jih lahko ljudje spet zadovoljujejo. V tej tekmi pa človek ne more izpolniti potrebe po samouresničevanju, kot jo je opredelil ustanovitelj humanistične psihologije Abraham Maslow ali kot jo imenuje slavni logoterapevt Viktor E. Frankl - potreba po smislu (Lukas, 1993). Govori o tem, da smisla ne moremo dati, smisel je treba najti. Lahko pa damo zgled. Enako razmišlja o vrednotah. Vrednot ne moremo učiti, moramo jih živeti. Živimo pa jih za tiste, ki pridejo za nami. Družina je tista prva, je šolski zgled tega, kaj pomeni biti nekaj, biti za nekoga in biti drug za drugega.

V zvezi s cilji permanentnega izobraževanja Paul Lengrand (1970, IV) razlaga, da to ni preprosto podaljšanje tradicionalnega izobra-

Zdravstvena statistika $\mathrm{v}$ vseh razvitih $\mathrm{dr}$ žavah kaže skokovito naraščanje števila nevroz, psihosomatskih bolezni, samomorov in zasvojenosti. To ni nić čudnega, saj Živi večina ljudi v vedno večjem nasprotju s svojimi telesnimi, psihološkimi in socialnimi potrebami.

ževanja, temveč niz novih pristopov $\mathrm{k}$ osnovnim življenjskim prvinam vsakega človeka. Omogoča, da se posameznik bolje pripravi na spremembe v svojem življenju, da oblikuje bolj kakovostne odnose $\mathrm{z}$ drugimi ljudmi, vštevši svojega partnerja in otroke, da je kos napredku in spremembam $\mathrm{v}$ svojem poklicnem delu, da zna poiskati zadovoljstvo $\mathrm{v}$ kulturi, športu in v družbi, v kateri živi. Človeku pomaga najti smisel, pomembno pa je predvsem, da ga usposobi, da bo znal pomagati drugim, predvsem mlajšim generacijam, da bodo lažje našle svoj smisel.
Ladi Škerbinek Psibiatrična klinika $v$ Ljubljani 


\section{IZOBRAŽEVANJE ZA ZDRAVJE}

Če se vrnem k zdravju, bi lahko primerjali idejo ter potrebo po vseživljenjskem izobraževanju in iskali v vsem tem tudi vseživljenjsko izobraževanje za zdravje. To se kaže v strategiji Zdravje za vse do leta 2000. Njeni osnovni cilji so bili sprejeti v SZO (Svetovna zdravstvena organizacija) leta 1978, regionalni cilji za Evropo pa 1984. Za Slovenijo je ta strategija povzeta v dokumentu Plan zdravstvenega varstva RS do leta 2000, ki ga je izdalo Ministrstvo za zdravstvo leta 1993.

Osnovna podlaga dokumenta je široko pojmovanje zdravja in bolezni, ne samo kot fizičnega, ampak tudi psihičnega in socialnega pojava. Zdravje je pojmovano kot proces, $v$ katerega so pri reševanju zdravstvenih problemov vključeni tisti, ki imajo probleme (in jih v razvitem svetu imenujemo najpogosteje kliente), in tisti, ki imajo ustrezno strokovno znanje, da lahko pomägajo.

Temeljna naloga zdravstvenega varstva je doseči čim višjo raven zdravja $\mathrm{v}$ fizičnem, psihičnem in socialnem smislu. Vzgojnozdravstveno delo mora vključevati znanje iz zdravstva in tudi iz pedagoških, psiholoških ter socioloških ved. Pomeni kontinuirane stike $\mathrm{z}$ ljudmi $\mathrm{v}$ vseh življenjskih obdobjih, kadar so zdravi oziroma bolani. Ti stiki so pomemben dejavnik pri oblikovanju človekovega odnosa do zdravja, načina življenja in okòlja.

Gre za zahtevno nalogo, katere cilj je z izboljšanjem kakovosti življenja v vseh življenjskih obdobjih dodajanje let življenju in življenja letom.

Tako kot so načela permanentnega izobraževanja $v$ naši družbi temeljna filozofija predvsem $\mathrm{v}$ andragoških ustanovah in pri posameznikih, ki se skušajo po tem tudi ravnati, je tudi strategija SZO bolj na papirju, v praksi pa je manj pogosta. Uveljavitev permanentnega izobraževanja zahteva:

- preoblikovanje celotnega formalnega sistema izobraževanja,

- nove subjekte kot nosilce in izvajalce izobraževanja,

- udeleženec izobraževanja postane aktivni dejavnik pri lastnem učenju (naučiti ga učiti in naučiti ga imeti potrebo po učiti se);

strategija Zdravje vsem do leta 2000 pa:

- preoblikovanje zdravstva $\mathrm{z}$ večjim poudarkom na preventivnem delovanju,
- sprememba v izobraževanju zdravstvenih delavcev in razširitev vzgojnozdravstvenega dela kot sestavine permanentnega izobraževanja,

- udeleženci zdravstvenih storitev postanejo aktivni dejavnik pri lastnem zdravljenju.

Zakaj bi bilo v zvezi duševnim zdravjem drugače kot na drugih področjih $\mathrm{v}$ zdravstvu itd.?

Ali lahko iščemo povezave med posameznikovo izobraženostjo (s tem ne mislim samo na formalno stopnjo šolske izobrazbe, ampak tudi na njegovo znanje in vzgojo, ki ju je pridobil z neformalnim izobraževanjem in samoizobraževanjem) in duševnim zdravjem ali splošnim zdravjem?

Strategija razvoja Zdravje vsem do leta 2000 je dokument, ki ni samo rezultat pozitivnega razmiśljanja, temveć tudi rezultat raziskav strokovnjakov o tem, da bo drugačen pogled na zdravje, drugačen odnos do njega, večja izobraženost v zvezi z adravjen, njegovim ohranjanjem in aktivno posameznikovo sodelovanje v skrbi za lastno zdravje obrodilo uspehe.

Z gotovostjo lahko trdimo, da bomo to povezavo našli in da nam jo bo uspelo tudi dokazati. Navsezadnje je človeštvo $\mathrm{z}$ zavzetostjo in znanjem odpravilo mnogo pandemičnih bolezni. Kljub tej gotovosti pa $\mathbf{v}$ psihiatriji malokrat iščemo stične točke med posameznikovo izobraženostjo in duševnimi motnjami. Učenje in pridobivanje novega znanja ter spretnosti je pomembno predvsem pri zdravstvenih delavcih, ki delajo v psihiatriji. Vzgoja in izobraževanje bolnikov pa je del terapevtskega postopka in ju vsebuje rehabilitacijski postopek v celoti. Terapija je vedno proces učenja.

\section{DUŠEVNE MOTNJE VZROKI}

Vzroki duševnih motenj so zelo različni. Nekatere motnje so posledica interakcije med biološko ranljivostjo in stresnimi situacijami, ki nastajajo v okolju, nekatere pa posledica telesnih (organskih) obolenj in zastrupitev. Pri večjem številu duševnih motenj pa gre za posledico hujše in trajne duševne obremenitve, ki se lahko povezuje še z dedno dispozicijo (Musek, 
1993). Vzroki hujših in trajnih duševnih obremenitev so lahko že obdobja normalnega osebnega razvoja ali pa stresi in krize.

$\mathrm{Za}$ vsemi, izrazitimi in manj izrazitimi bolezenskimi simptomi pa tiči le človek. Simptomi so njegov odgovor na razmere, v katerih je prisiljen živeti.

Posameznikov osebnostni razvoj lahko razdelimo na pet večjih razvojnih obdobij: otroštvo, mladostno dobo, odraslo dobo, dobo zrelosti in starost. Za posamezno obdobje so značilne spremembe, ki zadevajo vsa področja osebnosti in v zvezi s tem tudi vedenja: telesno in duševno (motivacijsko, čustveno, zaznavno, miselno, moralno) ter socialno (odnosi z drugimi ljudmi). V vsakem življenjskem obdobju se spoprijemamo z novimi nalogami in problemi. Zato tudi prihaja $\mathrm{v}$ razvoju do kritičnih obdobij in kriz. $\mathrm{V}$ tem pogledu so posebno občutljiva nekatera obdobja (zgodnje otroštvo - potreba po varnosti; odraslo obdobje - ustvarjanje družine; doba zrelosti - kriza srednjih let, odhajanje otrok; starost - upokojitev, izguba partnerja).

Erickson (1959) je prvi razdelil krizo na dva glavna tipa, in sicer razvojno in situacijsko. Prve nastajajo v določenih življenjskih obdobjih pri vseh ljudeh v večjem ali manjšem obsegu, druga pa povzročajo nepričakovani življenjski dogodki, za katere je običajno značilna pomembna izguba. Žrtev krize skuša obdržati svojo homeostazo z okoljem. Ko je ta zaradi psihičnih ali fizioloških dejavnikov ogrožena, bo skušala rešiti problem. Če ti poskusi spodletijo, je zmedena, vznemirjena in izgubljena. Če se kriza ne reši, ampak še poglablja, žrtev krize zapade v dezorganizacijo osebnosti.

V zelo obsežni raziskavi so dali nekaj tisoč ljudem oceniti, kateri dogodki povzročajo življenjske krize (Musek, 1994). Ocenjevalci so jih takole razvrstili, od najbolj do najmanj stresnega dogodka:

- smrt zakonca,

- ločitev,

- odvzem prostosti (zapor),

- smrt bližnjega sorodnika,

- huda nesreča, bolezen, invalidnost,

- izguba službe,

- upokojitev,

- nosečnost,
- težave pri spolnih odnosih,

- finančne težave,

- smrt dobrega prijatelja,

- zamenjava poklica,

- ločitev od otrok,

- začetek šolanja.

Med najpomembnejši vprašanji, ki se vsiljujejo pri problematiki psihičnih stresov in obremenitev, je vprašanje, od česa so odvisni izvidi delovanja stresorjev. $\mathrm{V}$ zadnjih 30 letih so $\mathrm{s}$ številnimi raziskavami dokazali, da obstaja tesna povezava med stresnimi življenjskimi dogodki in psihičnimi težavami. Kljub temu pa, tako navaja Musek (1994), korelacija med količino stresnega dogajanja in mentalnim zdravjem ter dobrim počutjem ni tako velika. Že dolgo je znano, da se na stresne situacije različno odzi-
Večina duševnih motenj je posledica daljšin duševnih obremenitev. vamo. Od posameznikovih osebnostnih značilnosti, obdobja in njegovega stanja je odvisno, kako se bo spopadel s stresi in psihičnimi obremenitvami. Premagovanje stresa in psihičnih obremenitev je odvisno od čustvene zrelosti in stabilnosti. Druge osebnostne lastnosti niso tako pomembne kot zrelost, vendar jih ne kaže zanemarjati. Med osebnostne lastnosti, ki vplivajo na premagovanje stresa in psihičnih obremenitev, štejemo:

- čustveno stabilnost,

- občutek nadzora in kompetentnosti,

- način premagovanja stresa in obrambnega reagiranja,

- empatijo, zmožnost vživljanja,

- altruizem, pripravljenost pomagati,

- značilnosti medsebojnega obnašanja,

- sposobnosti, znanje, spretnosti.

\section{KLASIFIKACIJA DUŠEVNIH MOTENJ}

Psihiatrija je veda o zdravljenju človekove osebnosti (duše), se pravi veda, ki preučuje odklonske in bolezenske (abnormalne) pojave človekove osebnosti, ki se kažejo v spremembah človekovega vedenja in doživljanja, in jih skuša odpravljati.

Če se psihiatrija kot veda ukvarja z zdravljenjem, pomeni, da predvideva obstoj duševne bolezni ali motnje pri človeku. Vsakdo ima $\mathrm{v}$ 


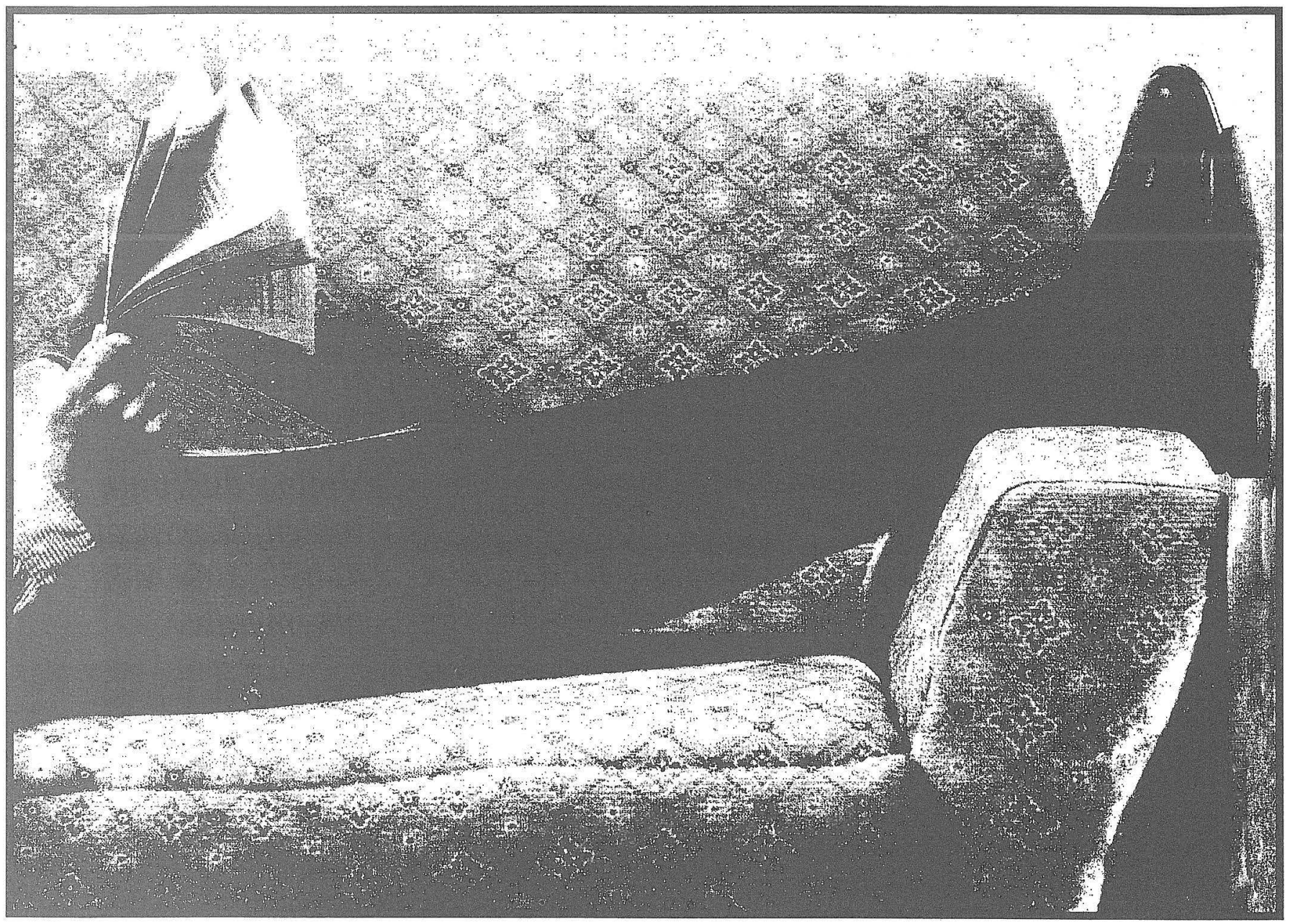

določenih življenjskih okoliščinah težave pri obvladovanju vsakdanjih problemov in obveznosti ali pa jih pogosto sploh ne more obvladati. To lahko povzroči različne telesne motnje $\mathrm{z}$ duševnim ozadjem, povezane s pretiranim stresom in z znamenji motenega duševnega funkcioniranja (huda tesnobnost), še večkrat pa to, čemur rečemo v najširšsem smislu depresivne razpoloženjske motnje. Nemalokrat so ta stanja za posameznika tako boleča, da poišče ustrezno pomoč in zdravljenje ali pa ga tja napotijo svojci, prijatelji, znanci. »Prave« duševne bolezni pa se kažejo v različnih stopnjah tesnobnosti, zaznavnih motenj (prividi in prisluhi), izkrivljenem doživljanju realnosti (blodnje) in hudih nihanjih razpoloženja iz ene skrajnosti $v$ drugo. Te bolezni praviloma zahtevajo dolgotrajnejšo pomoč in zdravljenje, ki lahko privedejo do različnih stopenj ozdravitve, včasih pa se dajo opisani bolezenski znaki le odpraviti.

V psihiatriji so si desetletja prizadevali klasificirati in opredeliti psihične motnje. Vendar psihično sliko vedno določa tudi človekova osebnost. Kljub temu pa jih je bilo treba zaradi strokovnega sporazumevanja nekako klasificirati v skupine:

1. Skupina psihoreaktivnih, nevrotskih oziroma osebnostnih motenj, ki jo označuje razmeroma blaga simptomika. Organskih vzrokov ni mogoče odkriti, dednostni dejavniki so manj pomembni. Te motnje so najbolj razumljive, če se opremo na dinamično psihološke mehanizme.

2. Skupina endogenih psihičnih obolenj, pri katerih so izraziti simptomi, vendar pri tem praviloma niso prizadete zavest in intelektualne funkcije. Organski vzroki niso znani, pomembni pa so dednostni dejavniki.

3. Skupina organskih motenj $z$ organskimi razlogi, v simptomiki se pojavljajo motnje zavesti, spominu in inteligenci.

Kljub tej delitvi v posamezne skupine pa so zadnja desetletja prinesla nekaj novega. Kakor hitro bolnika namreč ne opazujemo več ločenega od njegovega okolja, postane njegovo prej nerazumljivo vedenje in doživljanje iznenada povsem logično. 


\section{PRIMERJAVA NEKATERIH DUŠEVNIH MOTENI ZARADI STAROSTII (ŽIVLJENJSKEGA OBDOBJA) IN IZOBRAZBE}

V svojem prispevku primerjam duševne motnje posameznih diagnostičnih skupin po starosti in izobrazbi. Želela sem se izogniti duševnim motnjam, pri katerih se ugotavljajo tudi organski razlogi, in največji skupini endogenih psihičnih obolenj. Navajam primerjavo in poskus analize za nevrotske motnje, akutno prilagoditveno depresivno reakcijo in samomor in poskus samomora.

Zbiranje statističnih podatkov o formalni izobrazbi klientov temelji na klasifikaciji, ki zajema devet kategorij:

- brez izobrazbe,

- osnovna šola,

- poklicna šola,

- srednja šola,

- višja šola,

- visoka šola,

- neznano,

- ni podatka,

- in drugo.

V kategorijo »ni podatka « štejemo vse upokojence in tiste, ki so zavarovani kot »občani«. Ti podatki so tako pomanjkljivi, da jih težko uporabimo za kakršnokoli resno sklepanje o vzročni povezavi med stopnjo izobrazbe in duševno motnjo. Vse skupaj seveda še zaplete dinamika vzročnosti duševnih motenj. Razlog je $\mathrm{v}$ tem, da vzrokov duševnih motenj še vedno ne poznamo v celoti.

\section{NEVROTSKE MOTNJE}

Obstajajo duševne motnje brez organske osnove, ki se kažejo s simptomi spremenjenega subjektivnega doživljanja in vedenja in $\mathrm{s}$ funkcionalnimi motnjami. Ozadje teh motenj sta iztirjen osebnosten razvoj in konfliktna naravnanost $\mathrm{v}$ razmerju do sebe in sveta. $\mathrm{Na}$ stanejo zaradi zavestnih ali podzavestnih čustvenih problemov človeka. Vzroke nevroz pripisujejo predvsem vzgoji nevrotičnih staršev, ki ovira razvoj otrokove osebnosti. Kasneje ne more ustvariti zdravega ravnotežja $v$ sebi in $\mathrm{z}$ drugimi.

Starostna struktura pacientov je značilna za
Starostna struktura sprejetih pacientov - nevrotske motnje

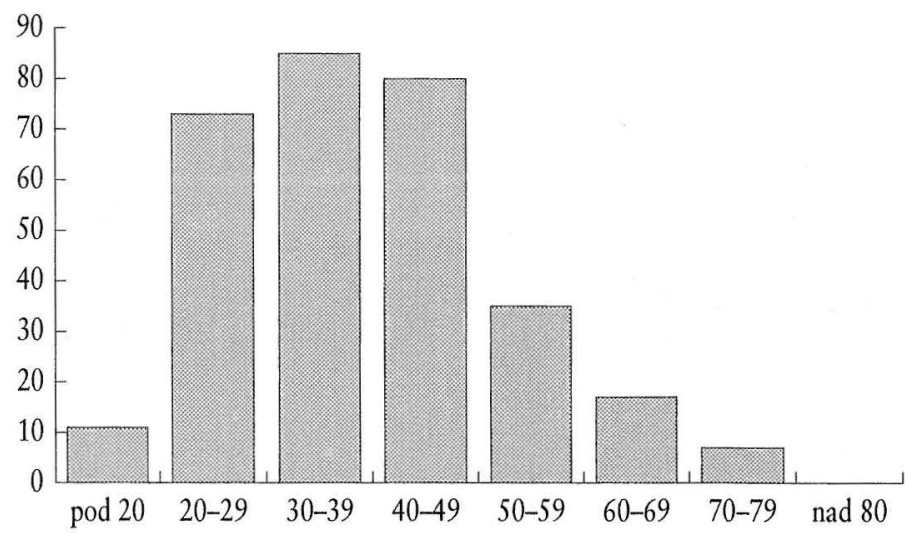

Struktura pacientov glede na izobrazbo - nevrotske motnje

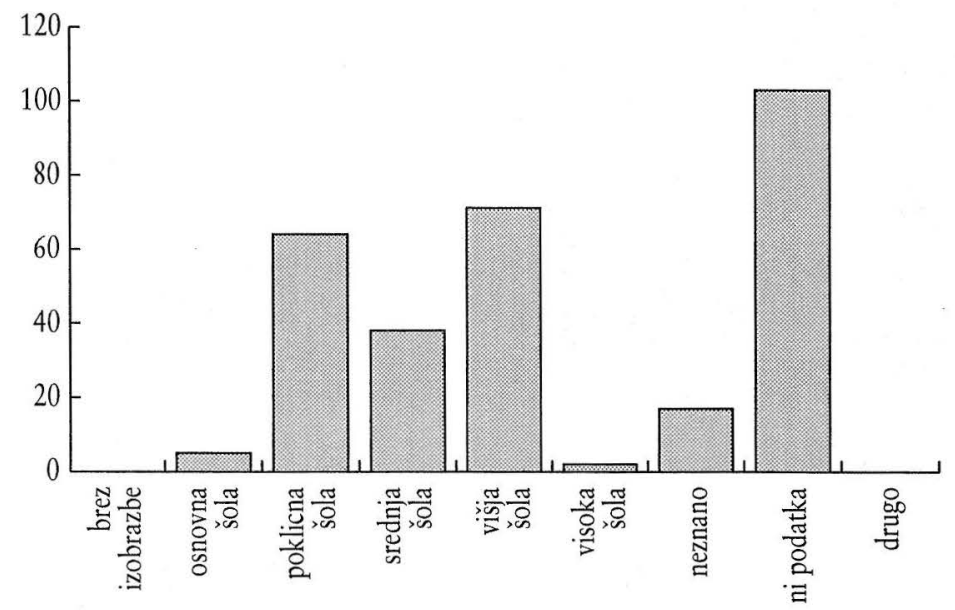

nevrotske motnje. Največ jih je starih od 20 do 49 let, torej v odraslem življenjskem obdobju. Lahko si razlagamo, da prihaja pri človeku $v$ teh obdobjih do hujših obremenitev in zato tudi do hujših simptomov pri nevrotsko strukturirani osebi. Po izobrazbi imajo pacienti večinoma poklicno, srednjo in višjo šolo. Samo 103 primeri z oznako "ni podatka« kaže na to, da nevrotske motnje ne vplivajo toliko na socialno-ekonomski status, zato se ta zaradi bolezni ne poslabša, kot se običajno zgodi pri bolnih s psihozo.

\section{AKUTNA PRILAGODITVENA DEPRESIVNA REAKCIJA}

Zanjo so značilne akutne reakcije na stres in reakcije prilagajanja. Akutne reakcije na stres so odgovori na izjemen fizični ali psihični 


\section{Starostna struktura sprejetih pacientov - akutna prilagoditvena depresivna reakcija}

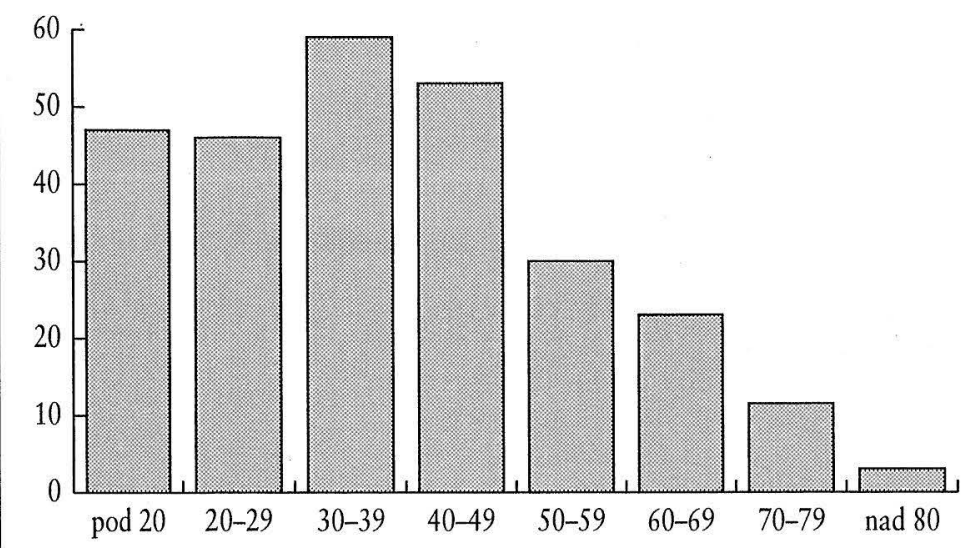

Struktura pacientov glede na izobrazbo - akutna prilagoditvena depresivna reakcija

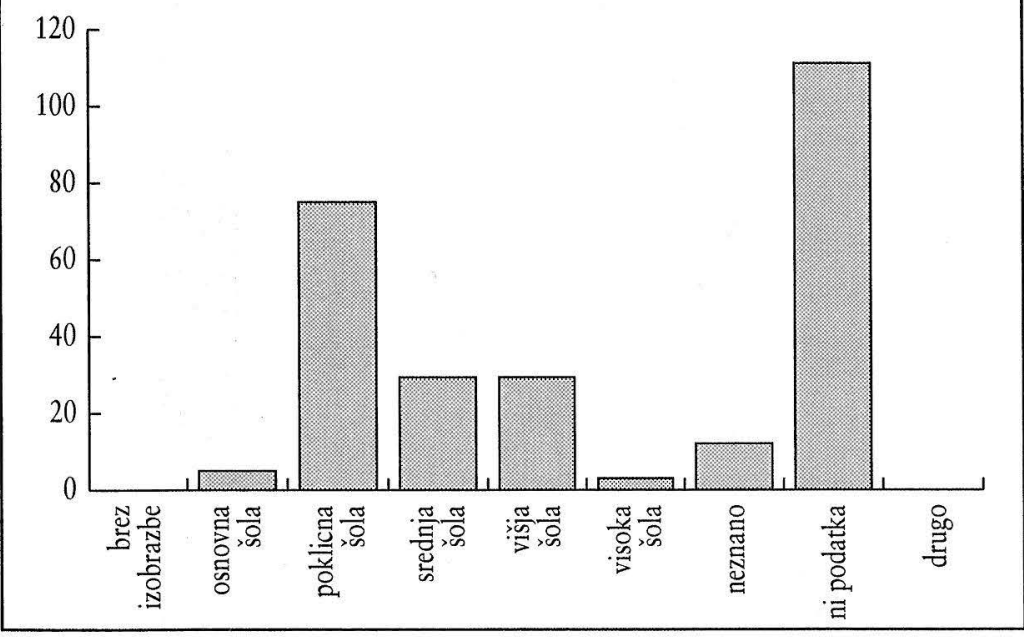

stres in običajno hitro izzvenijo, prilagoditvene reakcije pa trajajo dalj časa. Pri obeh je odločilen eksogeni element, tu je patogeno doživetje.

V letu 1994 je bilo sprejetih 268 bolnikov s to diagnozo, 175 jih je bilo sprejetih prvič, 93 pa je bilo recidivov.

Starostna struktura je po številu primerov precej enakomerno razporejena. Število upada po 60. letu. Po izobrazbi prevladujejo pacienti s poklicno šolo. Pri 111 pacientih je bila $v$ zvezi s podatkom o izobrazbi oznaka $» n i$ podatka «, kar kaže na izgubo ali probleme z zaposlitvijo. V tej kategoriji so številčno najmočnejše starostne skupine do 49. leta. Kljub nezanesljivosti statističnih podatkov o stopnji izobrazbe bi bilo mogoče sklepati, da se aku-

\section{SAMOMORI IN POSKUS SAMOMORA}

Samomor je premišljen konec lastnega življenja, poskus samomora pa je avtoagresivno dejanje, pri katerem človek ostane živ. Značilno za tako vedenje je, da praviloma ni neposredna reakcija na psihično travmo ali obremenitev, temveč je to konec procesa. Zadnja stopnja tega vedenja pa je nezrel, fantazijski odnos do smrti. Vzroke iščemo v osebnostnih in zunanjih dejavnikih.

V letu 1994 je bilo obravnavanih 122 bolnikov iz te diagnostične skupine, 90 prvič in 32 recidivov.

Za posamezne starostne skupine je značilno, da je največ pacientov starih do 20 let, nato pa njihovo število po 39. letu upada. Očitno zreli odrasli ljudje lažje obvladujejo samomorilno vedenje. Po izobrazbi je najštevilčnejša skupina s poklicno šolo in skupina $» n i$ podatka «, kar nakazuje na možnost, da se samomorilno vedenje večkrat pojavlja pri ljudeh $s$ formalno nižjo izobrazbo.

Kljub primerjavi tako pomanjkljivih podatkov o formalni izobrazbi bolnikov v posameznem vzorcu lahko sklepamo o na splošno formalno manj izobraženih ljudeh, ki iščejo pomoč zaradi duševnih motenj.

\begin{tabular}{|c|c|c|}
\hline Socidhis islej & Nerroze frodstalixit] & Pithoze V odstokth \\
\hline WI shiping & 65 & 35 \\
\hline His skeping & 45 & 55 \\
\hline N. skuping & 23 & 7 \\
\hline V, skiping & 9 & भा \\
\hline
\end{tabular}

Številne raziskave so pokazale, da je pri nižjih slojih več duševnih motenj in bolezni kot $\mathrm{v}$ višjih. To je razvidno iz tabele, $v$ kateri je prikazan odstotek vrste duševnih obolenj pri posameznih slojih (s I. skupino je označen najvišji socialni sloj, s V. skupino pa najnižji - nekvalificirani in priučeni delavci).

\section{SKLEP}

Danes vemo, da telesnih in duševnih bolezni ne moremo povsem izenačevati. Pri duševnih motnjah in boleznih imamo opraviti z zgodovinsko pogojeno motnjo osebnosti. Telesna bolezen je vedno bolezen enega dela organizma - čeprav gre kasneje za celostno reakcijo, je $v$ zvezi z duševnostjo $v$ vsaki reakciji združeno celotno duševno življenje. To pomeni, krat pojavlja pri ljudeh z nižjo izobrazbo. 
da je pri človeku vsaka oblika vedenja - vsakdanje življenje, mišljenje, čustvovanje, hotenje, sanje itd. - izraz enotnega specifično celostnega življenjskega "stila «. Organske bolezni se da opisati v jeziku dejstev, duševno dogajanje pa je izraz smiselne dejavnosti osebnosti oziroma njeno stališče. Celo še pri tako velikem regresu osebnosti je vsak trenutek opazen smisel in cilj je zbežati pred grozečo sedanjostjo v pretekli, lepši, boljši svet.

$\mathrm{S}$ temi spoznanji o duševnih motnjah in boleznih pa se mora njihovo zdravljenje bistveno spremeniti. Le medikamentozno zdravljenje ni posebno učinkovito. Zadnje čase v psihiatriji uporabljamo metode, ki jih imenujemo psihoterapija. Poteka tako, da $\mathrm{z}$ bolnikom razpravljamo in mu svetujemo, kako naj ravna, ga skušamo usposobiti, da bi obvladoval določene življenjske težave, $\mathrm{z}$ njim odkrivati in odpravljati zavestne in podzavestne vzroke njegovih notranjih in zunanjih konfliktov. Psihoterapevtska situacija je vedno proces učenja in $\mathrm{v}$ pravem smislu proces permanentnega izobraževanja. Bolnik ni več le pasivni objekt zdravstvene obravnave, temveč sodela$v e c$ in dejaven subjekt $v$ procesu, $v$ katerem je za dober izid pomemben tudi njegov lastni delež in prizadevanje. Taka obravnava ljudi z duševnimi motnjami zmanjšuje socialno izolacijo in identitetne težave.

Čeprav je splošna predstava ljudi o duševni bolezni še vedno povezana predvsem s pojmom psihoz, pa raziskave o razširjenosti duševnih motenj kažejo drugačno podobo. Kljub določenemu, dokaj nespremenljivemu deležu, ki ga klasične duševne bolezni, zlasti shizofrenske in druge psihoze, zavzemajo pri populaciji, pa so mnogo pogostejše druge oblike duševnih motenj. Te so še bolj odločilne za splošno stanje duševnega zdravja pri določeni populaciji. Glede na svojo pogostost tudi mnogo bolj zmanjšujejo kakovost življenja prebivalstva in povzročijo hudo trpljenje posameznika in njegovih najbližjih.

Najbolj razširjene so depresija, anksioznost

Pri liudeh $\mathrm{z}$ duševnimi motnjami in boleznimi ne iščemo več varokov samo $v$ njih samih, temveč gledamo na bolnikove simptome kot na individualno prelomljena družbena protislovja, protislovja družbe.

\section{Starostna struktura sprejetih pacientov - samomor in poskus samomora}

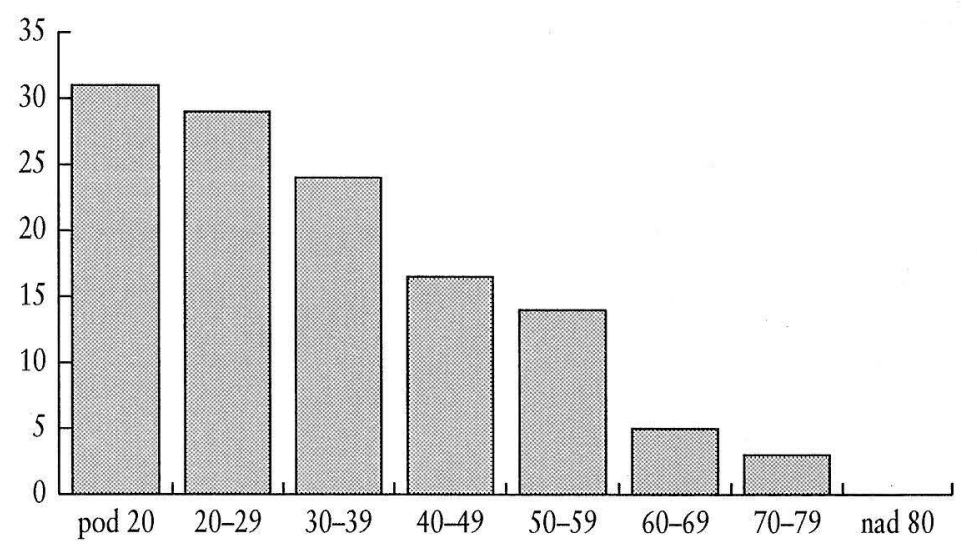

Pregled pacientov glede na izobrazbo - samomor in poskus samomora

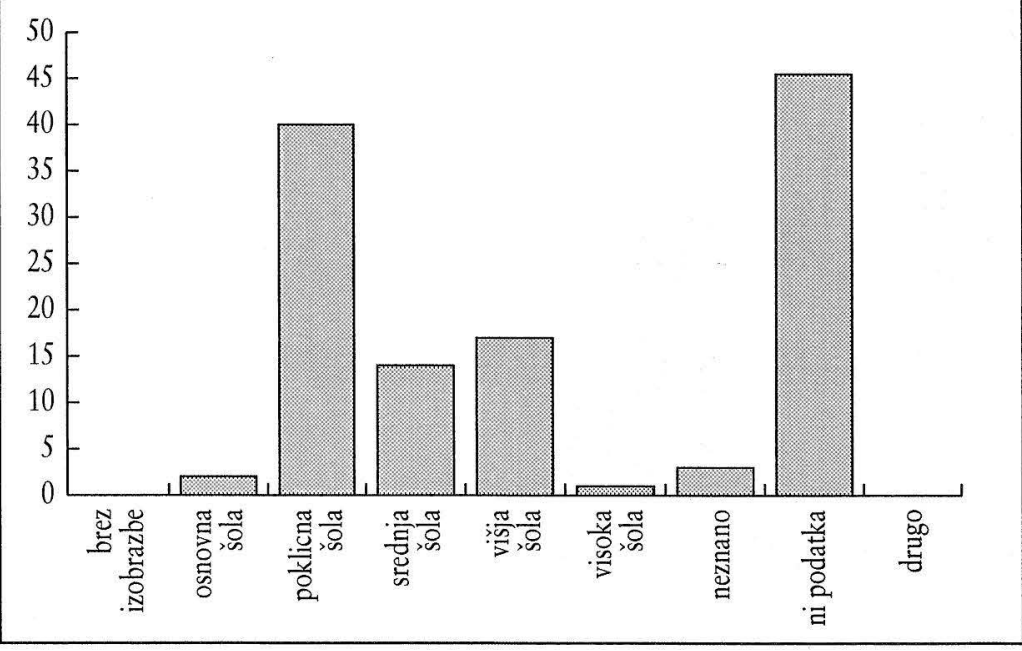

(tesnoba) in različne motnje zaradi prilagajanja na zunanje obremenitve. To so motnje, ki po svoji pogostosti in po načinu pojavljanja in omejevanja skoraj vseh duševnih funkcij najbolj odločilno posegajo $v$ življenje precejšnjega dela populacije.

Posameznik lahko z zdravim načinom življenja in z osveščenim odnosom do vrednot, ki so njegov sestavni del, krepi poleg telesnega zdravja tudi duševno.

Prav ta celovitost duševnega zdravja kot širša vrednota postavlja $\mathrm{v}$ posebno vlogo tistega, $\mathrm{ki}$ trpi, in tistega, ki mu želi in mu je tudi dolžan pomagati. Psihiatrija pa s seznanjanjem tistih, ki odločajo o pomenu ustreznih pogojev za življenje, v katerem je mogoče premagovati notranje napetosti in zunanje obremenitve na bolj zdrav način, ne sme biti edina. 
Znan pregovor pravi, da je bolje preprečevati kot zdraviti, zato je pri zagotavljanju duševnega zdravja razumljiva velika vloga vzgoje in izobraževanja. Tako je treba tiste, ki zbolijo, spodbujati, da se vključijo v dejavno življenje, svojce oseb z duševnimi motnjami pa pripraviti k sodelovanju. Predvsem je potrebno delovati na področju osveščanja ljudi za splošne vrednote duševnega zdravja.

Preprečevanje duševnih motenj med prebivalstvom je zelo zahteven proces, ki vključuje politične, medicinske, socialne, psihološke, ekonomske in druge ukrepe. Vseživljenjsko permanentno izobraževanje je pomemben dejavnik v preventivnem delu za doseganje duševnega zdravja. Vključevati bi moralo permanentno vzgojo čustev, vzgojo $k$ odpornosti do porabniške družbe, $\mathrm{k}$ zdravi storilnostni motivaciji, $\mathrm{k}$ odpravi togih socialnih vlog, $\mathrm{ki}$ so povezane s spolom, $\mathrm{z}$ vzgojo $\mathrm{k}$ različnosti, k neagresivnosti oziroma konstruktivni agresivnosti, z vzgojo $\mathrm{k}$ solidarnosti in sodelovanju, h kulturnosti in zdravemu načinu življenja. Obenem bi moralo permanentno izobraževanje vsebovati tudi vzgojo za uravnoteženo življenje v kritičnih obdobjih človekovega življenja. Tako o razvojnih pogojih otrok in mladostnikov, o izbiri poklica in partnerja, kot o staranju in starosti.

Predvsem pa je permanentno izobraževanje pomembno $\mathrm{v}$ tistem delu, da posameznika pripravi na razmišljanje o sebi in svetu, $\mathrm{v}$ katerem živi, da bo le ta storil vse za razumnejše in humanejše odnose med ljudmi.

\section{LITERATURA}

Bras S. in ostali (1978): Psihiatrija. DDU Univerzum, Ljubljana.

Erickson E. H. (1959): Identity of Life Cycle. Psychological Issues Monographs, International Universities Press, New York.

Lengrand P. (1970): Uvod v permanentno izobraževanje. Beogradski izdavačko grafički zavod Beograd.

Lengrand P. (1975): Človek v razvoju. Beogradski izdavačko grafički zavod Beograd.

Lukas E. (1993): Družina in smisel. Mohorjeva družba, Celje.

Musek J. (1993): Znanstvena podoba osebnosti. Educy, Ljubljana.

Musek J. (1994): Psihologija, Človek in družbeno okolje. Educy, Ljubljana.

Musek J. (1994): Stres, krize in osebna čustva. Uprava Republike Slovenije za zaščito in reševanje pri Ministrstvu za obrambo, Ljubljana.

V. Polič (1994): Psihološki vidiki nesreč. Uprava Republike Slovenije za zaščito in reševanje pri Ministrstvu za obrambo, Ljubljana.

Požarnik H. (1978): Kako ohranimo duševno zdravje. Mladinska knjiga, Ljubljana.

Ramon S. (1993): Razvoj duševnega zdravja v skupnosti v Veliki Britaniji in severni Ameriki. Socialno delo, 32: 5-18. 